\title{
Using the Balanced Scorecard to Measure the Performance of Small and Medium- Sized Garment Enterprises in Vietnam
}

\author{
Kim Anh Vu Thi ${ }^{1}$, Thuy Duong Vu ${ }^{1} \&$ Khanh Van Hoang ${ }^{2}$ \\ ${ }^{1}$ Trade Union University, Faculty of Accounting, Vietnam \\ ${ }^{2}$ University of Labour and Social Affairs, Faculty of Accounting Vietnam \\ Corresponding author: Kim Anh Vu Thi, Trade Union University, Faculty of Accounting, Vietnam
}

Received: July 24, 2018

Accepted: August 5, 2018

Online Published: August 8, 2018

doi:10.5430/afr.v7n3p251

URL: https://doi.org/10.5430/afr.v7n3p251

\begin{abstract}
Improving performance is always a strategic issue for any business operating in the market economy, as it is an important basis for the survival and development of the business. In order to evaluate the performance of enterprises, it is necessary to use financial and non-financial indicators. In models of appreciation of performance, the Balanced Scorecard (BSC) is one of the best model. Thus, this research sought to determine the application of BSC to measure the performance suitable for small and medium-sized (SMEs) garment enterprises in Vietnam. The research design was a survey conducted on a target population of the garment companies in Vietnam with a sample size of 238 garment SMEs. The study used questionnaires in data collection. In order to analyze the data, the research tested the reliability of the observation variable and performed exploratory factor analysis to examine the convergence of the observed variables in appling BSC to set up a rating system for garment SMEs. The study found that the indicators in the financial perspective for garment SMEs only include the traditional financial criteria taken from accounting books. On the other hand, in terms of internal processes, the research also adds the following criteria: Supplier-to-Supplier ratio, Supplier-to-Supplier Timeliness, Supplier Percentage Regularly supplied to the enterprise. These indicators are highly appreciated by managers of garment SMEs and in line with the production characteristics of garment SMEs in Vietnam.
\end{abstract}

Keywords: balanced scorecard, performance measures, small and medium-sized enterprises, Vietnam

\section{Introduction}

It is widely acknowledged among management authorities and practitioners that what you cannot measure, you cannot effectively manage. Performance measurement can be defined as the process of quantifying the efficiency and effectiveness of action (Neely et al, 2005). It is "the periodic measurement of progress toward explicit short-run and long run objectives and the reporting of the results to decision makers in an attempt to improve program performance" (Neely et al, 2005).

Letza (1996) showed the main function of performance measurement in a strategic context, is to provide the means of control to achieve the objectives required in order to fulfill the company"s mission/strategy statement. This view is supported by Neely et al (1994) who view performance measurement as a key part of "strategic control". Fawcett et al (2007) developed this argument by stating the need for performance measurement to exercise this control through: helping managers to identify good performance, setting targets and demonstrating success or failure. Development of an effective measurement system is a crucial task for any organization exposed to tough competition (Thakkar et al, 2007) and it must be an integral part of the management process.

Ghobadian \& Gallear (1997) found that the resource limitations associated with SMEs indicated that the dimensions of quality and time were critical to ensure that waste levels were kept low, and that a high level of productivity performance was attained. Similarly, the reliance on a small number of customers suggested that to remain competitive, SMEs have to ensure that customer satisfaction remained high and that they had to be flexible enough to respond rapidly to changes in the market. Lack of a monetary safety for SMEs to absorb the impact of short term fluctuations resulting from change means that the financial dimension of performance is more critical for them than their larger counterparts. The effective monitoring of the human resource dimension of SMEs is also paramount as the flatter structure of SMEs means that employees often have a greater number of job roles and more responsibility. In these circumstances, a well-trained and motivated workforce is important. Santori \& Anderson (1987) stressed the 
importance of non-financial measures in monitoring and motivating the progress of the human factor of the organization.

With globalization of markets, garment SMEs have many opportunities but also many challenges. In order to enhance the competitiveness of the market, SMEs should not only formulate financial strategies but also include non-financial strategies. In models of appreciation of performance, the Balanced Scorecard (BSC) model is widely appreciated by many businesses. BSC provides managers with a holistic, visionary, strategic vision into a set of indicators in four perspectives: Finance, Customer, Internal Process, Learning \& Growth. Many of the world's companies operate in different areas, using the Balanced Scorecard to evaluate garment SMEs. Vietnamese companies in general and garment SMEs in particular need a comprehensive system of evaluation. In brief, there are compelling reasons why garment SMEs should use BSC in evaluating the performance of the business with the indicator system associated with the development strategy of the enterprise.

The paper will continue with a quick intro- duction on the BSC and a brief literature review on the BSC research, leading to the reasons for this study. Then research method- ology follows with research design, study method and a discussion on the analytical framework that is used to analyse the imple- mentation issues. The last three parts are empirical findings, discussion on the findings and conclusion.

\section{Overview of Research}

In the early 1990's, Kaplan \& Norton introduced BSC as an integrated device that facilitates the formal use of non-financial information in evaluating the effectiveness of business units (Kaplan \& Norton, 1992). According to Kaplan \& Norton (1996) proposed the development of a Balanced Scorecard rating system that includes Financial and non- financial indicators are linked in a causal relation to the strategic implications of specific performance goals in terms of: Finance, Customer, Business Process, Learning and Growth.

Hoque \& James (2000) investigated the effect of scale on the application of BSC in the evaluation of the performance. We conducted a survey of 66 manufacturing companies in Australia. The size of the organization is measured by the team through three measures: Total sales, Total assets, Number of employees. Quantitative research results show that the larger the scale, the greater the degree of BSC adoption. Another study on the ability of BSC to implement strategy and business management in Hong Kong companies "Perception and Applicability of the Balanced Scorecard in Hong Kong Organizations" by Ping (2006). The author conducted a survey of 50 companies on the Hong Kong Stock Exchange in various business areas. The objective of the study was to analyze the differences between companies using BSC and BSC unused companies.

A study on the application BSC in small and medium enterprises of Sofian,S et al (2015) confirmed the role of BSC in strategic management for small and medium enterprises. Another study on the use of BSC in small and medium enterprises was studied in the UK and Cyprus by Giannopoulos et al (2013). Authors conducted a survey of 500 small and medium enterprises in the UK \& Cyprus. Questionnaires are mostly closed questions that are addressed to managers of these businesses. The questions revolve around the use of BSC in these operations. The results showed that SMEs are highly appreciative of the role of BSC in the review of Korean equities despite the fact that BSC has only been used in recent years.

The research by Chimwani et al (2013) sought to determine the application of Balanced Scorecard in measuring performance in SMEs manufacturing enterprises in Kenya. The study found that there was a gap between the knowledge of customer perspective, internal business perspective and innovation/learning and growth perspective measures and their application in SMEs. Business managers should identify the critical internal business processes which the firm must excel at and should identify the infrastructure that the organization must build to create longterm growth and improvement of its people, systems and organizational structure. For manufacturing SMEs this will eventually translate to the competitiveness hence profitability of the firms.

Suanmali et al. (2009) discussed the establishment of Key Performance Indicators (KPIs) for the measurement of corporate social responsibility in Thai garment companies through the BSC. According to Karabay \& Kurumer (2012) suggested that the proposed BSC does not apply to all companies. The purpose of this study is to provide a starting point for the establishment of an effective management system that will help companies to implement the strategy in a new competitive environment "Key Success Factors for Organizational Innovation in the Fashion"

Felice \& Petrillo (2013) pointed out the system of evaluation performance for the fashion industry in Italy. "A Consolidated Model of Putting BSC into Action in Textile Industry in Pakistan", Maqbool (2015) proposed that performance evaluation model with six views instead of the four typical views of Kaplan and Norton: Financial Customer - Supply Chain and Market - Sustainability - Learning \& Growth. Maqbool (2015) proposed that 
performance evaluation model with six views instead of the four typical views of Kaplan \& Norton (Financial Customer - Supply Chain and Market - Sustainability - Learning \& Growth.

Starting from the review, the authors found that the application of BSC in the evaluation of the performance is very important and that the application of BSC in enterprises of different sizes will be different. However, in studies on the use of BSC in garment enterprises in the world and inVietnam, there are no studies in Vietnam on the use of BSC in assessing performance in garment SMEs in Vietnam. Thus, this study will implement the application of BSC to measure the performance suitable for SMEs garment enterprises in Vietnam with objectives: (1): Clarify the role of the BSC in assessing the performance of the business; (2): Evaluate the status of using the BSC to evaluate the performance of garment SMEs in Vietnam; (3): Applying BSC to evaluate the performance suitable for garment SMEs in Vietnam.

\section{Literature Review}

\subsection{Balanced Scorecard}

BSC was first introduced by Kaplan \& Norton (1992) as a set of measures that provided top managers with fast, comprehensive views of businesses with four perspectives edge of the balanced scorecard. However, the causal relationship between dimensions was not thoroughly investigated at this stage. Kaplan \& Norton (1992) working with 12 companies at the leading edge of performance measurement, devised a balanced scorecard - a set of measures that gives top managers a fast but comprehensive view of the business. The balanced scorecard includes financial measures that tell the results of actions already taken. And it complements the financial measures with operational measures on customer satisfaction, internal processes and the organisations innovation and improvement activities - operational measures that are the drivers of future financial performance.

They further add that the balanced scorecard measures differ from those traditionally used by companies given they are grounded in the organizations strategic objectives and competitive demands as opposed to being bottom-up and derived from ad-hoc processes. By requiring managers to select a limited number of critical indicators within each set of the four perspectives, the scorecard helps focus this strategic vision. In addition, while traditional financial measures report on what happened last period without indicating how managers can improve performance in the next, the scorecard functions as the cornerstone of a company's current and future success. Kaplan \& Norton (1996a) state that the balanced scorecard complements financial measures of past performance with measures of the drivers of future performance. The objectives and measures of the scorecard are derived from an organisations vision and strategy. The objectives and measures view organizational performance from four perspectives: financial, customer, internal business process and learning \& growth.

BSC captures the critical value creation activities created by skilled, motivated organizational participants. While retaining via the financial perspective, an interest in short-term performance, the balanced scorecard clearly reveals the value drivers for superior long term financial and competitive performance (Kaplan \& Norton, 1996b)

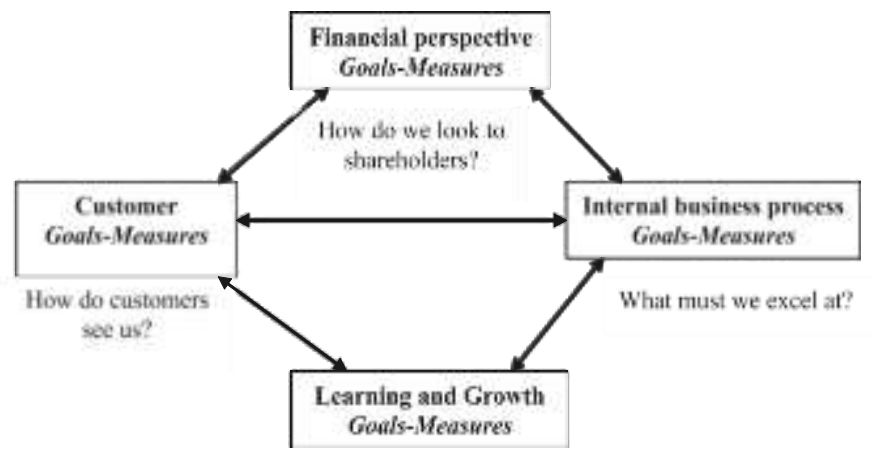

Can we continue to improve and

create value?

Figure 1. The strategy map

(Source: Kaplan \& Norton, 1996b)

The figure 1 shows BSC includes four perspectives, which are Learning and Growth perspective, Internal Business perspective, Customers perspective and financial perspective. Order of each of these four perspectives can be flexible to meet strategies of an organization. 


\section{The first, Financial Perspective}

Financial measures remain an important dimension within the BSC. Financial performance measures indicate whether a company's strategy, implementation, and execution are contributing to bottom-line improvement. They indicated how well a company is performing with respect to its profitability targets (Decoene \& Bruggeman, 2006). They have to do with a firm"s performance and resource management. Financial performance measures are retrospective performance measures that reflect the results of past managerial actions and an exclusive reliance on them causes organizations to sub-optimize (Kaplan \& Norton, 1996a). From a financial perspective, return on equity, return on assets, cash flow, earnings per share, sales, earnings before income tax (EBIT), sales/ total assets, return on capital employed, fixed costs, labour costs, scrap, rework, revenue growth, profit margins, cash flow and net operating income are performance measures generally agreed on.

\section{The second, Customer Perspective}

In the customer perspective, managers identify the customer and market segments in which the business unit will compete and the measures of the business unit's performance in these targeted segments. This perspective typically includes several core or generic measures of successful outcomes from a well formulated and implemented strategy. The core outcome measures include customer satisfaction, customer retention, new customer acquisition, customer profitability and market and account share in targeted segments. The segment specific drivers of core customer outcomes represent those factors that are critical for customers to switch or remain loyal to their suppliers. The customer perspective enables business unit managers to articulate the customer and market based strategy that will deliver superior future financial returns (Kaplan \& Norton,1996b).

\section{The third, Internal Business Process Perspective}

Internal business process measures indicate the level of a company's performance with respect to activities that are critical to meet customer and financial objectives (Decoene \& Bruggeman, 2006). They also indicate what the firm must do internally to meet its customers expectations. The core competencies and the critical technologies are identified and measured to ensure market leadership (Thakkar et al, 2007). They have to be carefully designed by those who know the internal processes of the firm most intimately, as they should be derived from the firm"s unique vision and mission statement/strategy. A decision is then made.

\section{The fourth, Learning \& Growth Perspective}

The Learning and Growth perspective identifies the infrastructure that the organisation must build to create long term growth and improvement. Organisational learning and growth come from three principal sources: people, systems and organizational procedures. The financial, customer and internal business process objectives of the BSC typically will reveal large gaps between the existing capabilities of people, systems and procedures and what will be required to achieve breakthrough performance. To close these gaps, businesses will have to invest in reskilling employees, enhancing information technology and systems and aligning organizational procedures and routines. These objectives are articulated in the learning and growth perspective of the BSC (Kaplan \& Norton, 1996b).

\subsection{Performance Evaluation}

An economic category is an economic measure that measures the viability and sustainability of an enterprise through the value it generates. The added value of the business is the added value of shareholder investments or the added value of the resources that the business spends. Value can be a combination of both the financial goal and the non-financial objective. With the goal of finance, the value created is the value of shareholders. For non-financial goals, the value includes benefits for working conditions, working time, social interaction.

In order to assess the effectiveness of the operation, the enterprises need a suitable indicator system, which is closely linked with the target and strategy of the enterprise reflect the comprehensive performace of enterprises and at the same time, it should be attached with the development strategy of the enterprise, namely: (1): The measurement criteria of the international standard must be in line with the development strategy of the enterprise; (2): The criteria of measurement of performace must be linked with the vision, values and key success factors of enterprises; (3): The norms of measurement of performace must reflect the past, present and future associated with the operation of enterprises; (4): The norms of measurement of performace should reflect the needs of customers, shareholders and employees; (5): The norms of measurement of performace must be consistent and coherent between the higher level and the lower level of the enterprise; (6): The norms of measurement of the country need to change when the business strategy of the enterprise changes; (7): The norms of measurement of the performace should be reliable; (8): The norms of measuring performace should reflect the specific objectives of the enterprise; (9): The measurement system of the 
international standard must include the financial criteria and non- financial criteria.

\subsection{Appling a Balanced Scorecard to Assess the Performance of Your Business}

BSC is used as a communication tool to communicate strategy in a clear, concise manner to all members involved both inside and outside the organization through strategic maps. Based on the four- perspective model of BSC, strategy map adds a second layer of detailed information that illustrates the dynamics of a strategy at time- based; strategy map provides a consistent way to describe strategies, so that measures and objectives can be established and managed, it provides the links between strategy execution and strategy formulation (Kaplan \& Norton, 2004).

According to Kaplan and Norton, strategy map links companies'core objectives into each stage such as the development of employee knowledge, high quality products and customer satisfaction, which are linked to the companies' value chain. With a strong cause and effect relationship character, strategy map links objectives with indicators, for instance the lead indicator which comes before any other indicators and lag indictor that comes after (Kaplan \& Norton, 2004).

The strategy map provides the cause- and- effect relationship between four perspectives of BSC, the result of this aspect is the cause of other aspects. Financial aspects for people to know the financial situation of the company through indicators such as ROI, ROA and ROE. The interest of shareholders always towards the financial indicators. However, the financial indicators only give a glimpse of past and present business activities, not meeting the long-term development strategy. Thus, non-financial indicators are expressed through the remaining three aspects which could give an overview of the goals and strategies of business development. The aim of the organization is to gain profit by fulfilled the customers need. Conduct service excellent in the internal process able to increase customer satisfaction and relationship between the organization and the customer. The result is that the customer becomes loyal to the organization and conducts the customer retention. This customer value proposition clarifies how to generate sales from targeted customers. Thus, the internal business aspect creates the superiority in the short and long term of the strategy, creating the factor to develop value added for customers. In a competitive environment, the added value of the customer increases as the customer's business side becomes successful. And that will lead to the success of the financial aspect, creating added value for shareholders. To achieve the strategic objectives in long term the business should focus on Learning and Growth where the company had to increase the ability to the employees. Since the organization core business is on services, the objectives must in-line with the core business of the organization for instance create customer-focused culture and develop strategic competencies by providing proper training and development to the employee frequently. Besides that, by attracting and retaining top talent, thisincreases employee satisfaction and they are able to make employees more engaged to the organization.

\section{Research Methods}

For the study, the authors used both quantitative and qualitative research methods.

With the qualitative research method, the authors conducted semi-structured and unstructured interviews, and then conducted a pilot study. In the In-Depth Questionnaire, the author uses semi-structured and unstructured questions. For the purpose of research, the author recommends that enterprises apply BSC to evaluate the company's performance in accordance with its development strategy. Therefore, the interviewees were managers whom the authors are interested in the needs of managers in the enterprise want to use any indicator in BSC.

After the in-depth interview, the authors found that most Vietnamese garment enterprises do not currently have a suitable rating system. At present, Vietnamese garment companies are of the opinion that the construction of a comprehensive evaluation system is urgent. On the other hand, from the in-depth interview, the authors find that the current appropriate indicator system needs to have current values: Economic Value Added (EVA), Market Value Added (MVA), Cash flow return on investment (CFROI). In addition, through the results of the interview, the authors also added indicators: proportion of suppliers meet the requirements; Timely delivery time for suppliers; Percentage provider is a regular supplier to the business.

The majority of SMEs in Vietnam are mainly engaged in processing garment processing, products are placed according to the requirements of customers, according to author's statistics, the general strategy of garment SMEs is focused on improving the quality of services, meeting the requirements of customers, focusing on developing the domestic market. Based on the results of the survey, the authors have summarized the development strategy of garment SMEs, namely:

- Increase profits

- Expanding the size of the business 
- To concentrate and expand the domestic consumption market

- Improve and improve services, product quality

- On time delivery

- Find more customers

- Attract and use rational human resources

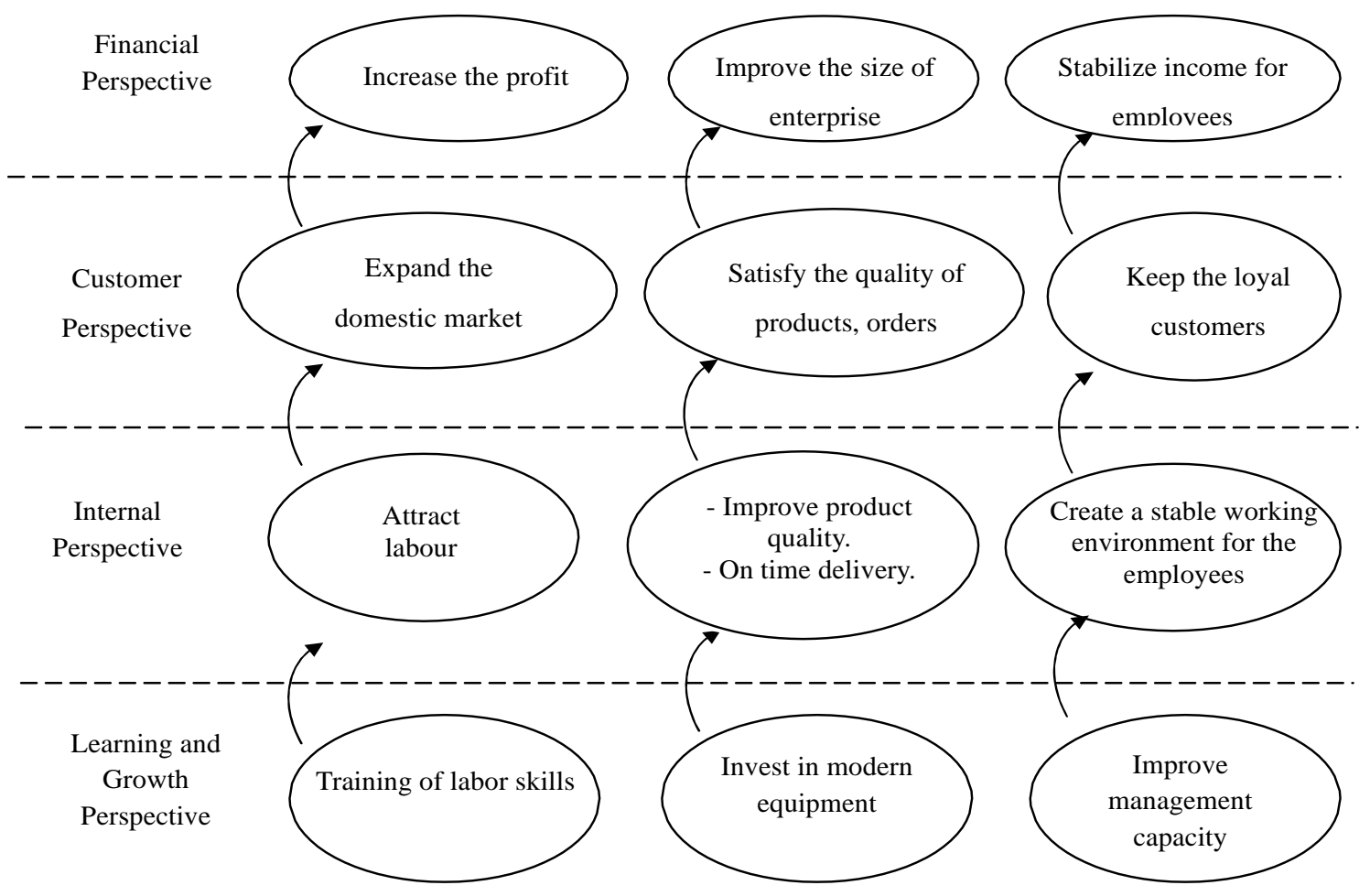

Figure 2. The strategy map of the garment SMEs in Vietnam

With quantitative research, the authors used SPSS 19 software in data processing. Data analysis is done through the statistical description of the sample and the observation variable. Afterwards, the authors assesses the reliability of the scale and Analyze the EFA Discovery Factor to examine the convergence of the observed variables. Based on the research results of this, the authors have made suggestions to improve the efficiency of using the Balanced Scorecard to evaluate the performance of garment SMEs in Vietnam.

\section{Samping method}

Based on the formula of Hair et al (2006) which demonstrated that an appropriate sample size for a study using factor analysis, should be at least 5 times the total number of observation variables.

$\mathrm{n}=5 * \mathrm{~m}$ (n: number of samples to choose; $\mathrm{m}$ : number of observations)

Thus, with the 47 observed variables of the four expected factors, the minimum sample size was: $\mathrm{n}=5 * 47=235$ samples. In the study, the authors examined data in 250 firms. As a result, 238 listed firms are chosen. Table 1 shows variables and its measurement in the model. 
Table 1. Variables and Its Measurement

\begin{tabular}{|c|c|c|}
\hline Name of Variables & Code & Resourse \\
\hline \multicolumn{3}{|l|}{ Financial perspective } \\
\hline Revenue growth rate & FINAN1.01 & $\begin{array}{l}\text { Singh and Schmidgall (2002); Chriyha et al } \\
\text { (2012) }\end{array}$ \\
\hline Revenue / employee growth rate & FINAN2.02 & $\begin{array}{l}\text { Singh and Schmidgall (2002); Chriyha et al } \\
\text { (2012) }\end{array}$ \\
\hline Profitability ratio & FINAN3.03 & $\begin{array}{l}\text { Singh and Schmidgall (2002); Chriyha et al } \\
\text { (2012) }\end{array}$ \\
\hline Return on Investment (ROI) & FINAN4.04 & $\begin{array}{l}\text { Singh and Schmidgall (2002); Chriyha et al } \\
\text { (2012) }\end{array}$ \\
\hline Return on Assets (ROA) & FINAN5.05 & $\begin{array}{l}\text { Singh and Schmidgall (2002); Chriyha et al } \\
\text { (2012) }\end{array}$ \\
\hline Return on Equity (ROE) & FINAN6.06 & $\begin{array}{l}\text { Singh and Schmidgall (2002); Chriyha et al } \\
\text { (2012) }\end{array}$ \\
\hline Profitability of turnover & FINAN7.07 & $\begin{array}{l}\text { Singh and Schmidgall (2002); Chriyha et al } \\
\text { (2012) }\end{array}$ \\
\hline Gross profit margin & FINAN8.08 & $\begin{array}{l}\text { Singh and Schmidgall (2002); Chriyha et al } \\
\text { (2012) }\end{array}$ \\
\hline Return on Capital Used (ROCE) & FINAN9.09 & $\begin{array}{l}\text { Singh and Schmidgall (2002); Chriyha et al } \\
\text { (2012) }\end{array}$ \\
\hline Rate of return on cost & FINAN10.10 & $\begin{array}{l}\text { Singh and Schmidgall (2002); Chriyha et al } \\
\text { (2012) }\end{array}$ \\
\hline Rate of profitability of fixed assets & FINAN11.11 & $\begin{array}{l}\text { Singh and Schmidgall (2002); Chriyha et al } \\
\text { (2012) }\end{array}$ \\
\hline Rate of stock price increase & FINAN12.12 & $\begin{array}{l}\text { Singh and Schmidgall (2002); Chriyha et al } \\
\text { (2012) }\end{array}$ \\
\hline The rate of increase of dividends & FINAN13.13 & $\begin{array}{l}\text { Singh and Schmidgall (2002); Chriyha et al } \\
\text { (2012) }\end{array}$ \\
\hline Profit rate of common stock & FINAN14.14 & $\begin{array}{l}\text { Singh and Schmidgall (2002); Chriyha et al } \\
\text { (2012) }\end{array}$ \\
\hline Total cost reduction ratio & FINAN15.15 & Singh \& Schmidgall (2002); Chriyha et al (2012) \\
\hline Rate of unit cost reduction & FINAN16.16 & Singh \& Schmidgall (2002); Chriyha et al (2012) \\
\hline Economic value increases (EVA) & FINAN17.17 & Anand et al (2005) \\
\hline Increased market value (MVA) & FINAN18.18 & Anand et al (2005) \\
\hline Return on Investment (CFROI) & FINAN19.19 & Anand et al (2005) \\
\hline \multicolumn{3}{|l|}{ Customer perspective } \\
\hline Number of complaints / customers & CUS1.20 & $\begin{array}{l}\text { Karabay \& Kurumer (2012); Felice \& Petrillo } \\
\text { (2013); Chriyha et al (2012). }\end{array}$ \\
\hline Time to settle a complaint & CUS2.21 & $\begin{array}{l}\text { Karabay \& Kurumer (2012); Felice \& Petrillo } \\
\text { (2013); Chriyha et al (2012). }\end{array}$ \\
\hline The percentage of customers leaving the company & CUS3.22 & $\begin{array}{l}\text { Karabay \& Kurumer (2012); Felice \& Petrillo } \\
\text { (2013); Chriyha et al (2012). }\end{array}$ \\
\hline Frequent use of the product customer & CUS4.23 & $\begin{array}{l}\text { Karabay \& Kurumer (2012); Felice \& Petrillo } \\
\text { (2013); Chriyha et al (2012). }\end{array}$ \\
\hline Incorrect delivery rate & CUS5.24 & $\begin{array}{l}\text { Karabay \& Kurumer (2012); Felice \& Petrillo } \\
\text { (2013); Chriyha et al (2012). }\end{array}$ \\
\hline
\end{tabular}


The rate of turnover of new customers.

CUS6.25

The percentage of new customers who want to return.

CUS7.26

\section{Internal Business Process Perspective}

Sales rate of new products / total sales collection. INTER1.27

Revenue Ratio of New Market / Total revenue

INTER2.28

Rate of R \& D expenditure / total cost

INTER3.29

Rate of non-standard products

INTER4.30

Rate of Returned Goods

INTER5.31

New product ratio / total product

INTER6.32

Number of turns of inventory

INTER7.33

The storage time of the goods

INTER8.34

Time of freight

INTER9.35

Percentage of suppliers that meet the requirements INTER10.36

The rate of time the supplier delivers the goods properly duration

INTER11.37 Authors

The percentage of suppliers is usually the supplier

for the business.

INTER12.38

\section{Learning and Growth perspective}

Coefficient of renewal of equipment

LAG1.39

Proportion of indirect labors with postgraduate qualifications

LAG2.40

The percentage of indirect workers has a college degree

Proportion of indirect workers undergraduate level LAG4.42

The rate of direct labor with high skill level

LAG5.43

Rate of investment costs information equipment

LAG6.44

Proportion of employees wishing to work long long at the business

LAG7.45

Rate of exchange exchange experience work

LAG8.46

Rate of training costs, staff training/total cost

LAG9.47
Karabay \& Kurumer (2012); Felice \& Petrillo (2013); Chriyha et al (2012).

Karabay \& Kurumer (2012); Felice \& Petrillo (2013); Chriyha et al (2012).

Kaplan \& Norton (1996); Karabay \& Kurumer (2012); Felice \& Petrillo (2013)

Kaplan \& Norton (1996); Karabay \& Kurumer (2012); Felice \& Petrillo (2013)

Kaplan \& Norton (1996); Karabay \& Kurumer (2012); Felice \& Petrillo (2013)

Kaplan \& Norton (1996); Karabay \& Kurumer (2012); Felice \& Petrillo (2013)

Kaplan \& Norton (1996); Karabay \& Kurumer (2012); Felice \& Petrillo (2013)

Kaplan \& Norton (1996); Karabay \& Kurumer (2012); Felice \& Petrillo (2013)

Kaplan \& Norton (1996); Karabay \& Kurumer (2012); Felice \& Petrillo (2013)

Kaplan \& Norton (1996); Karabay \& Kurumer (2012); Felice \& Petrillo (2013)

Kaplan \& Norton (1996); Karabay \& Kurumer (2012); Felice \& Petrillo (2013)

Authors

Authors

Karabay \& Kurumer (2012), Felice \& Petrillo (2013); Chriyha et al (2012).

Karabay \& Kurumer (2012), Felice \& Petrillo (2013); Chriyha et al (2012).

Karabay \& Kurumer (2012), Felice \& Petrillo (2013); Chriyha et al (2012).

Karabay \& Kurumer (2012), Felice \& Petrillo (2013); Chriyha et al (2012).

Karabay \& Kurumer (2012), Felice \& Petrillo (2013); Chriyha et al (2012).

Karabay \& Kurumer (2012), Felice \& Petrillo (2013); Chriyha et al (2012).

Karabay \& Kurumer (2012), Felice \& Petrillo (2013); Chriyha et al (2012).

Karabay \& Kurumer (2012), Felice \& Petrillo (2013); Chriyha et al (2012).

Karabay \& Kurumer (2012), Felice \& Petrillo (2013); Chriyha et al (2012). 


\section{The method of data collection}

The questionnaire was divided into three parts which included open and closed questions The first section of the questionnaire sought general information about the particular enterprise such as the name of the business, which manufacturing sub-sector the business belonged to, the number of employees in the firm and the range of the previous year"s profit. The second section had close-ended questions based on a five point Likert scale from 1 to 5 (whereby $1=$ strongly disagree, $2=$ agree, $3=$ neutral, $4=$ agree and $5=$ strongly agree) to indicate the level of agreement to statements about performance measures. The third section also had close-ended questions based on a scale of 1 to 5 (whereby $1=$ to a very low extent, $2=$ to a low extent $3=$ moderately $4=$ to a high extent and $5=$ to a very high extent) to indicate level of application of BSC measurement perspectives.

\section{Results and Discussion}

\subsection{Research Results}

\section{Statistical description of the observation variable}

First, the authors decribled the level of use of indicators for the evaluation of business performance in the garment SMEs in Vietnam by determining the average value of the variable. This was the basis for the authors to assess the current status of application of BSC to evaluate business performance in the garment SMEs in Vietnam. Afterwards, the authors assessed the importance of indicators for the evaluation of business performance in the garment SMEs (See table 2 ).

Table 2. Descriptive Statistics

\begin{tabular}{|c|c|c|c|c|c|}
\hline & \multirow[b]{2}{*}{$\mathrm{N}$} & \multicolumn{2}{|c|}{ The level of use } & \multicolumn{2}{|c|}{ The level of importance } \\
\hline & & Mean & $\begin{array}{l}\text { Std. } \\
\text { Deviation }\end{array}$ & Mean & $\begin{array}{l}\text { Std. } \\
\text { Deviation }\end{array}$ \\
\hline FINAN1.01 & 238 & 4.5905 & .73884 & 3.8793 & .85438 \\
\hline FINAN2.02 & 238 & 1.5086 & .75588 & 3.9267 & .86228 \\
\hline FINAN3.03 & 238 & 4.7500 & .63621 & 3.9138 & .86859 \\
\hline FINAN4.04 & 238 & 4.8147 & .56227 & 3.8319 & .89357 \\
\hline FINAN5.05 & 238 & 4.2241 & .89816 & 3.9224 & .93652 \\
\hline FINAN6.06 & 238 & 4.3491 & 1.09844 & 4.2586 & .49448 \\
\hline FINAN7.07 & 238 & 4.4957 & .70249 & 4.0172 & .70842 \\
\hline FINAN8.08 & 238 & 2.3793 & .85438 & 3.3319 & .68832 \\
\hline FINAN9.09 & 238 & 2.1422 & .95868 & 4.0345 & .90627 \\
\hline FINAN10.10 & 238 & 3.5216 & .92557 & 3.5129 & 1.14332 \\
\hline FINAN11.11 & 238 & 1.5819 & .75146 & 3.6207 & .99048 \\
\hline FINAN12.12 & 238 & 1.4914 & .69626 & 4.0129 & 1.18971 \\
\hline FINAN13.13 & 238 & 4.7112 & .77194 & 2.6595 & 1.79236 \\
\hline FINAN14.14 & 238 & 1.6078 & .72466 & 2.9569 & 1.41661 \\
\hline FINAN15.15 & 238 & 4.5991 & .74937 & 2.7112 & 1.88828 \\
\hline FINAN16.16 & 238 & 3.3578 & 1.17938 & 2.2802 & .82909 \\
\hline FINAN17.17 & 238 & 1.5948 & .67713 & 3.4914 & .96695 \\
\hline FINAN18.18 & 238 & 1.6681 & .54829 & 3.9353 & 1.18071 \\
\hline FINAN19.19 & 238 & 1.6336 & .70820 & 3.3147 & 1.33878 \\
\hline CUS1.20 & 238 & 1.8966 & .72529 & 3.9828 & .13045 \\
\hline CUS2.21 & 238 & 1.5905 & .76758 & 3.8491 & .66359 \\
\hline CUS3.22 & 238 & 1.8793 & .71053 & 4.2672 & .66264 \\
\hline CUS4.23 & 238 & 3.6897 & .96172 & 4.1552 & .59001 \\
\hline
\end{tabular}




$\begin{array}{llllrl}\text { CUS5.24 } & 238 & 2.1250 & .95204 & 3.5733 & 1.06652 \\ \text { CUS6.25 } & 238 & 2.1552 & 1.05767 & 4.2845 & .59298 \\ \text { CUS7.26 } & 238 & 2.0388 & .73458 & 3.9310 & .76982 \\ \text { INTER1.27 } & 238 & 3.4224 & .84925 & 4.0991 & .71083 \\ \text { INTER2.28 } & 238 & 4.5086 & .85782 & 3.8707 & .92610 \\ \text { INTER3.29 } & 238 & 2.4138 & .83815 & 3.7371 & .74136 \\ \text { INTER4.30 } & 238 & 4.4871 & .83734 & 4.1940 & .66538 \\ \text { INTER5.31 } & 238 & 2.5388 & .90130 & 3.6034 & .66942 \\ \text { INTER6.32 } & 238 & 1.8448 & 1.09389 & 4.1724 & .68725 \\ \text { INTER7.33 } & 238 & 3.3922 & .98760 & 3.2371 & 1.06084 \\ \text { INTER8.34 } & 238 & 3.4095 & 1.17716 & 3.6983 & 1.08288 \\ \text { INTER9.35 } & 238 & 2.5216 & 1.38310 & 3.7716 & .70524 \\ \text { INTER10.36 } & 238 & 2.1034 & .96141 & 4.1509 & .64372 \\ \text { INTER11.37 } & 238 & 2.1767 & 1.07662 & 4.1853 & .67430 \\ \text { INTER12.38 } & 238 & 2.5474 & .84125 & 4.1121 & .69346 \\ \text { LAG1.39 } & 238 & 2.3362 & .85223 & 4.0043 & .78678 \\ \text { LAG2.40 } & 238 & 1.9052 & .71446 & 4.1724 & .62800 \\ \text { LAG3.41 } & 238 & 1.8017 & 1.17860 & 4.0043 & .66773 \\ \text { LAG4.42 } & 238 & 2.5603 & 1.02597 & 2.9871 & 1.11844 \\ \text { LAG5.43 } & 238 & 2.5388 & .99272 & 3.6940 & .83555 \\ \text { LAG6.44 } & 238 & 3.5216 & .77820 & 4.0733 & .70174 \\ \text { LAG7.45 } & 238 & 2.4957 & 1.55421 & 4.1595 & .80340 \\ \text { LAG8.46 } & 238 & 2.6207 & .81814 & 3.9741 & .82663 \\ \text { LAG9.47 } & 238 & 2.6466 & .90458 & 4.0560 & .70334\end{array}$

Valid N (listwise) 238

Assess the reliability of the scale

First, Assessment of the reliability of the scale in the Financial perspective: The third test result for the results obtained variables have the coefficient of correlation is equal to> 0.5 and Alpha coefficient $=0.802$ remaining 6 variables observed (See table 3)

Table 3. Testing result of the reliability of the scale in the financial perspective

Reliability Statistics

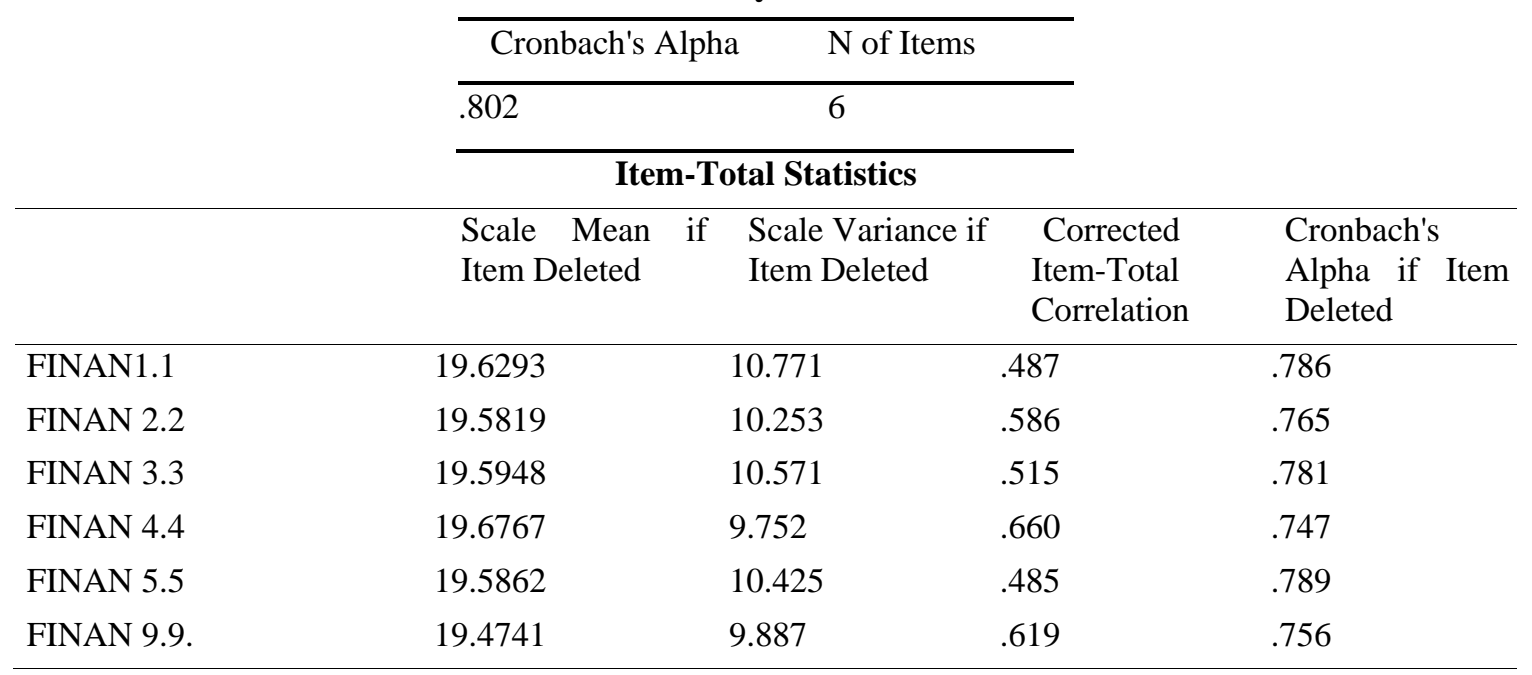


Second, Assessment of the reliability of the scale in the Customer perspective: The second test result for the Alpha coefficient $=0.825$ with the coefficients with the coefficient of correlation of $>0.3$ with the remaining 2 variables (See table 4)

Table 4. Testing result of the reliability of the scale in the customer perspective

Reliability Statistics

\begin{tabular}{ll}
\hline Cronbach's Alpha & N of Items \\
\hline 0.825 & 2 \\
\hline
\end{tabular}

Item-Total Statistics

\begin{tabular}{lllll}
\hline & $\begin{array}{l}\text { Scale Mean if Item } \\
\text { Deleted }\end{array}$ & $\begin{array}{l}\text { Scale Variance if } \\
\text { Item Deleted }\end{array}$ & $\begin{array}{l}\text { Corrected } \\
\text { Item-Total } \\
\text { Correlation }\end{array}$ & $\begin{array}{l}\text { Cronbach's Alpha } \\
\text { if Item Deleted }\end{array}$ \\
\hline CUS4.23 & 4.2845 & .352 & .702 & \\
CUS6.25 & 4.1552 & .348 & .702 & \\
\hline
\end{tabular}

Third, Internal businesss perspective: With the second result, the observed variables are retained satisfactorily with the total variance coefficient of $>0.5$ and the Alpha coefficient $=0.810$ with 6 variables (See table 5)

Table 5. Testing result of the reliability of the scale in the internal businesss perspective

\section{Reliability Statistics}

\begin{tabular}{cc}
\hline Cronbach's Alpha & N of Items \\
\hline 0.810 & 6 \\
\hline
\end{tabular}

Item-Total Statistics

\begin{tabular}{cccc}
$\begin{array}{c}\text { Scale Mean if } \\
\text { Item Deleted }\end{array}$ & $\begin{array}{c}\text { Scale Variance if } \\
\text { Item Deleted }\end{array}$ & $\begin{array}{c}\text { Corrected } \\
\text { Item-Total } \\
\text { Correlation }\end{array}$ & $\begin{array}{c}\text { Cronbach's } \\
\text { Alpha if Item } \\
\text { Deleted }\end{array}$ \\
\hline 20.8147 & 5.831 & .636 & .764 \\
\hline 20.7198 & 6.185 & .572 & .780 \\
\hline 20.7414 & 6.227 & .531 & .789 \\
\hline 20.7629 & 6.173 & .604 & .773 \\
\hline 20.7284 & 6.320 & .515 & .792 \\
\hline 20.8017 & 6.116 & .561 & .782
\end{tabular}

Fourth, Learning \& Growth perspective: The results of the second test of the observation variables have a total variable coefficient of $>0.5$ and an Alpha coefficient of 0.811 with 5 variables. Observation is retained (See table 6)

Table 6. Testing result of the reliability of the scale in the growth internal businesss perspective

\section{Reliability Statistics}

\begin{tabular}{ll}
\hline Cronbach's Alpha & N of Items \\
\hline 0.811 & 5 \\
\hline
\end{tabular}

Item-Total Statistics

\begin{tabular}{lllll}
\hline & $\begin{array}{l}\text { Scale Mean if } \\
\text { Item Deleted }\end{array}$ & $\begin{array}{l}\text { Scale Variance if } \\
\text { Item Deleted }\end{array}$ & $\begin{array}{c}\text { Corrected } \\
\text { Item-Total } \\
\text { Correlation }\end{array}$ & $\begin{array}{l}\text { Cronbach's Alpha } \\
\text { if Item Deleted }\end{array}$ \\
\hline LAG2 40 & 15.8276 & 5.052 & .616 & .771 \\
\hline LAG 3.41 & 15.9957 & 4.775 & .674 & .753 \\
\hline LAG 5.43 & 16.3060 & 5.157 & .351 & .861 \\
\hline LAG 6.44 & 15.9267 & 4.501 & .736 & .731 \\
\hline LAG 9.47 & 15.9440 & 4.599 & .694 & .745 \\
\hline
\end{tabular}




\section{Results of the EFA discovery factor analysis}

The results of the EFA factor analysis for the 19 observed variables after testing the Cronbach's Alpha showed that the LAG5.43 variable with a factor load factor $<0.5$ would removed. The authors continued to analyze the second EFA factor with the retained variables. Analysis results obtained the remaining variables have converged into 4 groups with coefficient $\mathrm{KMO}=0.777$ satisfactory (See table 7).

Table 7. Results of the EFA

\section{Pattern Matrix ${ }^{\mathrm{a}}$}

\begin{tabular}{|c|c|c|c|c|}
\hline & & & tor & \\
\hline & 1 & 2 & 3 & 4 \\
\hline INTER 1.27 & .731 & & & \\
\hline INTER 10. 36 & .692 & & & \\
\hline INTER 4. 30 & .643 & & & \\
\hline INTER 12. 38 & .632 & & & \\
\hline INTER 11.37 & .600 & & & \\
\hline INTER 6.32 & .579 & & & \\
\hline FINAN4. 4 & & .806 & & \\
\hline FINAN 9.9 & & .723 & & \\
\hline FINAN 2.2 & & .675 & & \\
\hline FINAN 5.5 & & .547 & & \\
\hline FINAN 1.1 & & .532 & & \\
\hline FINAN 3.3 & & .528 & & \\
\hline LAG6. 44 & & & .882 & \\
\hline LAG 9. 47 & & & .791 & \\
\hline LAG 3.41 & & & .733 & \\
\hline LAG 2.40 & & & .722 & \\
\hline LAG 4.23 & & & & .884 \\
\hline
\end{tabular}

\section{Discussion}

Based on the results of in-depth interviews, the results of the trial, the authors found that garment SMEs did not have access to the Balanced Scorecard. Despite the fact that the assessment of the performance in addition to the financial indicators uses non-financial indicators. However, indicators are mainly financial indicators. The evaluation of garment SMEs' market has not been based on the strategy of enterprise development.

In the other hand, for garment SMEs, the financial standards proposed by the authors in terms of finance: EVA, MVA, CFROI are not yet of interest to managers. As such, the indicators in the financial perspective for garment SMEs only include the traditional financial criteria taken from the accounting books. Indicators belonging to suppliers in the perspective of internal processes are also selected by the managers. 
Table 8. The application of Balanced Scorecard in measuring performance in small and SME garment enterprises

\begin{tabular}{|c|c|c|}
\hline Perspective & Objectives-Strategies & Measures \\
\hline \multirow{6}{*}{ Finance } & \multirow{6}{*}{$\begin{array}{l}\text { - Increase profits } \\
\text { - Stabilize income } \\
\text { employees }\end{array}$} & FINAN4.04. Return on Investment (ROI) \\
\hline & & FINAN 9 9. Return on Capital Used (ROCE) \\
\hline & & FINAN 2 2. Revenue / employee growth rate \\
\hline & & FINAN 11. Revenue growth rate \\
\hline & & FINAN 3 3. Profitability ratio \\
\hline & & INAN 5 5. Return on Assets (ROA) \\
\hline \multirow{6}{*}{$\begin{array}{l}\text { Internal } \\
\text { Business } \\
\text { Process }\end{array}$} & \multirow{6}{*}{$\begin{array}{l}\text { - Improve product quality } \\
\text { - Improve labor skills }\end{array}$} & INTER 4 30. Rate of non-standard products \\
\hline & & INTER 1 27. Sales rate of new products / total sales collection \\
\hline & & INTER 632 . New product ratio / total product \\
\hline & & INTER 1036 . Percentage of suppliers that meet the requirements \\
\hline & & $\begin{array}{l}\text { INTER } 1137 . \text { The rate of time the supplier delivers the goods } \\
\text { properly duration }\end{array}$ \\
\hline & & $\begin{array}{l}\text { INTER } 1238 \text {. The percentage of suppliers is usually the supplier for } \\
\text { the business. }\end{array}$ \\
\hline \multirow{4}{*}{$\begin{array}{l}\text { Learning an } \\
\text { Growth }\end{array}$} & - Training of labor skills & INTER 341 . The percentage of indirect workers has a college degree \\
\hline & d- Improve & ent qualifications $^{2}$ \\
\hline & & INTER 644 . Rate of investment costs information equipment \\
\hline & & INTER 9 47. Rate of training costs, staff training / total cost \\
\hline
\end{tabular}

Customer - Expand the domestic market CUS 625 . The rate of turnover of new customers.

- Satisfy the best products andCUS 423 . Frequent use of the product customer orders quality

- Maintain the loyal customers

\section{Conclusion and Recommendations}

The aim of the research was to establish the performance measures used in garment SMEs in Vietnam and to determine the extent of application of performance measures using the balance scorecard measurement perspectives. The research targeted 250 garment SMEs in Vietnam. The survey subjects were managers. Responses were received from 238 firms representing a response rate of 95.2 percent. Primary data was collected through a questionnaire with close- ended questions that enabled the collection of quantitative data.

The study found that the most common performance measures in garment SMEs in Vietnam were the traditional financial indicators. Garment SMEs were only interested in the short-term strategy of how businesses can survive in a fierce competition environment, thus profit targets were focused and managers were not paying attention to the EVA, MVA targets. However, the existence of measures from the internal business process and the innovation and learning/growth perspectives and their application was not very obvious. The findings indicated that 3 indicators: Proportion of suppliers meeting requirements, Proportion Time Supplier Supplier Timely, Supplier Percentage is a regular provider for businesses in the "Internal Process" perspective.

The research recommends that garment SMEs in Vietnam should supplement the traditional financial measures with non-financial measures: customer perspective measures, internal business perspectives measures and learning/growth measures (mentioned table 8). To improve the use of BSC to evaluate performance, garment SMEs should:

\footnotetext{
$\checkmark$ communicate strategy throughout the enterprise;

$\checkmark \quad$ align unit and individual goals with the strategy;

$\checkmark$ link strategic objectives to long-term tar- gets and annual budgets;

$\checkmark$ identify and align strategic initiatives; and
} 
conduct periodic performance reviews to learn about and improve strategy.

BSC is able to achieve a similar consis- tency of vision and action as they attempt to change direction and introduce new strategies and processes. BSC provides a framework for managing the implementation of strategy while also allowing the strategy itself to evolve in response to changes in the company's competitive, market, and technological environments.

\section{Limitations}

There are several limitations in this study. First, sample size is small; however, this is an unavoidable problem due to time constraint. Second, the scope of the research is limited to the garment SMEs in Vietnam, which only pay attention to the short-term strategy. Third, very little data about the system at the global and area level have been collected, thus it limits the understanding about the actual process of building a standard set of measures and targets, because the local firm and employees at country level have the role of users rather than system designers.

\section{Future research}

The following studies may examine the factors that affect the use of the balanced scorecard for evaluating marginal returns in Vietnamese garment enterprises. In-depth testing of geographic factors affects the use of balanced scorecards.

\section{References}

Chimwani, P.M., Onserio, N. \& Otuya, R. (2013). Application of Strategic performance measures in Small and Medium Sized Manufacturing Enterprises in Kenya: The Use of the Balanced Scorcard perspective. International Journal of Management Science and Business Research, 6.

Decoene V., Bruggeman W. (2006). Strategic alignment and middle-level managers' motivation in a balanced scorecard setting. International Journal of Operations \& Production Management, 26(4), 429-448. https://doi.org/10.1108/01443570610650576

Felice,F.D. \& Petrillo,A. (2013). Key Success Factors for Organizational Innovation in the Fashion Industry. International Journal of Engineering Business Management. https://doi.org/10.5772/56882

Fawcett, S.E., Osterhaus, P., Magnan, G.M., Brau, J.C., \& McCarter, M.C. (2007). Information sharing and supply chain performance: the role of connectivity and willingness. Supply Chain Management: An International Journal, 12(5), 358-368. https://doi.org/10.1108/13598540710776935

Giannopoulos, G., Holt, A., Khansalar, E., \& Cleanthous, S. (2013). The use of balanced scorecard in small companies. International Journal of Business and Management, 8(14), 1-22. https://doi.org/10.5539/ijbm.v8n14p1

Ghobadian A., Gallear D. (1997). TQM and organisation size, International Journal of Operations \& Production Management, 17(2), 121-63. https://doi.org/10.1108/01443579710158023

Hoque, Z., James, W. (2000). Linking Balanced Scorecard measures to size and market factors: impact on organizational performance. J. Manage. Acc. Res. 12, 1-17. https://doi.org/10.2308/jmar.2000.12.1.1

Kaplan R, S., \& Norton D. P (2004). How Strategy Maps Frame and Organization's Objectives. ABD/INFORM Global.

Kaplan,R.S., \& Norton,D.P (1992). The Balanced Scorecard: Measures That Drive Performance. Harvard Business Review.

Kaplan,R.S., \& Norton,D.P (1996a). The balanced scorecard: Translating strategy into action. Harvard Business Review.

Kaplan,R.S., \& Norton,D.P. (1996b). Using the Balanced Scorecard as a Strategic Management System. Harvard Business Review.

Kaplan,R.S. \& Norton,D.P. (2000). The Strategy focused organization: How Balanced Scorecard Companies threve in the new Business environment. Harvard Business Review.

Kaplan,R.S., \& Norton,D.P. (2001). Transforming the balanced scorecard from performance measurement to strategic management. Accounting Horizons, 15.

Karabay, G. \& Kurumer, G. (2012). Managing through Strategic Performance Management in Apparel Companies. Fibers \& Textiles in Eastern Europe, 20, 4(93), 13-19. 
Hair, J.F., et al. (2006). Multivaiate Data Analysis: Fifth Ed. Upper Saddle River, NJ: Prentice Hall,

Lawson, R. Stratton, W. \& Hatch, T. (2005). Achieving strategy with score carding. The Journal of Corporate Accounting \& Finance, March/April, 8-63.

Letza, S.R. (1996). The design and implementation of the balanced business scorecard, Business Process Re-engineering and Management Journal, 2(3), 54-76. https://doi.org/10.1108/14637159610151217

Maqbool,M.H. (2015). A Consolidated Model of Putting BSC into Action in Textile Industry in Pakistan.

Neely, A., Mills, J., Platts, K., Gregory, M., Richards, H. (1994). Realizing strategy through measurement. International Journal of Operations \& Production Management, 14(3), 140-52. https://doi.org/10.1108/01443579410058603

Neely, A., Gregory, M., J., Platts, K. (2005). Performance measurement system design: A literature review and research agenda. International Journal of Operations \& Production Management, 25(14), 1228-63.

Ping,S.W. (2006). Reception and Applicationlity of the Balanced Scorecard in HongKong Organizations.

Thakkar J., Deshmukh S.G., Gupta A.D., Shankar R. (2007). Development of a balance scorecard; an integrated approach of Interpretive Structural Modeling (ISM) and Analytic Network Process (ANP). International Journal of Operations \& Production Management, 56(1), 25-59.

Santori, P.R., Anderson, A.D. (1987). Manufacturing performance in the 1990s: measuring for excellence. Journal of Accountancy, 164(5), 141-7.

Sofian, S., Lonbani, M., \& Baroto, M. (2015). Linking Balanced Scorecard measures to SME's Business Strategy: Addressing the moderating role of Financial resources. International Journal of Research, Số 12, 92-99.

Suanmali, Suthathip, Ekkprawatt Phongarjarn, Chawalit Jeenanunta, Veeris Ammarapala, Kornthip Watcharapanyawong. (2009). A Study of Business Performance through Key Performance Indicators (KPIs) in Thai Garment Iridustry. http://chawalit.siit.tu.ac.th/lib/ exe/fetch.php?media=dissertations:icls54.pdf 